\title{
Evolução do pretérito imperfeito com valores modais no Português europeu
}

\section{Evolution of the Imperfect with Modal Functions in European Portuguese}

Jan Hricsina [Jan.hricsina@ff.cuni.cz]

Univerzita Karlova, República Checa

\section{RESUMo}

O objetivo do presente artigo é analisar o emprego do pretérito imperfeito na história da língua portuguesa a fim que se possa verificar qual o período da evolução do Português em que o pretérito imperfeito começou a exprimir os valores modais. A análise é efetuada no corpus linguístico diacrónico $w w w$. corpusdoportugues.org.

\section{Palavras-Chave}

linguística diacrónica; análise corporal; Português Europeu; pretérito imperfeito; funções modais

\section{Abstract}

The aim of this paper is to analyze the use of the imperfect tense in the history of the Portuguese language in order to find out in which period of the evolution of Portuguese the imperfect began to express modal values. The analysis is performed in the linguistic diachronic corpus www.corpusdoportugues.org.

\section{KEYWORDS}

diachronic linguistics; corpus analysis; European Portuguese; imperfect; modal functions 


\section{Introdução}

Um dos fenómenos que caracteriza o $\mathrm{PE}^{1}$ contemporâneo é um alargamento considerável dos conteúdos semânticos denotados pelo pretérito imperfeito. São os papéis modais ${ }^{2}$ que nos últimos tempos o pretérito imperfeito tem denotado com uma frequência cada vez maior, substituindo, assim, este paradigma sobretudo o condicional simples. É interessante ver que, no PB contemporâneo, esta tendência não seja tão forte. No Brasil, o condicional simples conserva a plena vitalidade. Um fenómeno semelhante pode ser encontrado também noutras línguas românicas. Diferentemente do que acontece com o PE, em que o pretérito imperfeito pode adquirir um leque considerável de valores hipotéticos, noutras línguas neolatinas, o conjunto de funções denotadas por este tempo não é tão grande. Em linhas gerais, podemos constatar que em Castelhano, Italiano e Francês, este tempo pode ser empregue nos pedidos atenuados ${ }^{3}$ e também em vários tipos de frases condicionais (Hamplová 1996: 201; Zavadil; Čermák 2010; Hamplová 2004: 190-191; Hendrich, Radina, Tláskal 1991: 421).

Basta fazer uma pesquisa rápida nas gramáticas históricas do Português para verificarmos que este fenómeno é relativamente recente. Nas fases remotas do Português, o pretérito imperfeito não era capaz de exprimir valores hipotéticos tão variados como na língua atual (ver mais adiante). Os livros que tratam a evolução do Português não referem também quais os motivos deste alargamento de funções denotadas pelo pretérito imperfeito. O objetivo do presente artigo será analisar o funcionamento do tempo em questão ${ }^{4}$ na história da língua portuguesa a fim de que possamos verificar qual o período da evolução do Português em que o pretérito imperfeito começou a exprimir os valores hipotéticos.

\section{Funcionamento do pretérito imperfeito no Português contemporâneo}

Em linhas gerais, pode dizer-se que o pretérito imperfeito é o paradigma que serve para exprimir processos ou estados que são anteriores ao momento da enunciação ${ }^{5}$. O emprego deste tempo depende do tipo da ação ou estado denotado pelo verbo: o primeiro tipo é representado pelos predicados estáveis. Este tipo de verbos denota geralmente estados de duração prolongada:

- O senhor Gomes era dentista. (uso) ${ }^{6}$

1 No presente artigo, a abreviatura PE representará o Português Europeu e PB o Português do Brasil.

2 Por papéis modais entendemos todas as funções consideradas como não-reais, ou seja, expressão de vários processos ou estados eventuais, possíveis ou condicionais.

3 Este tipo de emprego é possível também em Checo: Chtěl jsem se zeptat. (uso).

4 A análise será feita no corpus linguístico do Português www.corpusdoportugues.org (sobre os detalhes ver mais adiante).

5 O momento da enunciação representa o segmento temporal em que o discurso está proferido.

6 Todos os exemplos que se encontram nesta parte, vêm do uso do PE e foram criados pelo autor do artigo. Os exemplos que provêm doutras fontes, estão devidamente marcados. 
O outro tipo de predicados é representado pelos verbos que denotam seja estados temporários seja eventos. Nestas situações, os predicados são geralmente acompanhados ou por advérbios de tempo ou por uma oração, os quais criam, assim, um tempo de referência (Raposo 2013: 519-520):

- Ontem a Maria estava cansadíssima.

- João estava a telefonar, quando a sua mãe voltou do trabalho.

Sob outro ponto de vista, os processos ou estados expressos pelo pretérito imperfeito podem ser considerados como processos ou estados presentes "transportados" para o passado (Cunha, Cintra 1999: 450):

- Hoje a Maria está cansadíssima. > Ontem a Maria estava cansadíssima.

Este paradigma serve também para denotar ações repetidas ou habituais ocorridas no passado (Cunha; Cintra 1999: 450):

- A Inês voltava do trabalho às cinco.

Outro papel do tempo em questão é a expressão duma circunstância dos outros processos pontuais. Neste tipo de emprego, o pretérito imperfeito tem um carácter claramente cursivo (Svobodová 2014: 58):

- Tinha cinco anos quando comecei a jogar futebol.

O pretérito imperfeito pode exprimir também processos posteriores a outras ações situadas no passado. Neste papel, funciona como uma forma concorrencial do condicional simples ( $f a-$ laria) (Tláskal 1984: 244-245):

- Prometeu que vinha no dia seguinte.

Com verbos existenciais, o pretérito imperfeito serve para situar vagamente no tempo contos ou lendas (geralmente com o verbo ser) (Cunha, Cintra 1999: 451):

- Era uma vez um rei.

Excecionalmente, este paradigma pode denotar também processos pontuais e terminados caso a data ou o período em que ocorreram, esteja explicitamente expresso (Cunha, Cintra 1999: 453):

- John Lennon morria a 8 de dezembro de 1980. 
Em certos casos, a ação denotada pelo pretérito imperfeito pode prolongar-se do passado até ao presente, ou seja, ao momento da enunciação (Oliveira 1986: 89):

- Ninguém fala. Estávamos todos com fome. (Oliveira 1986: 89)

Como já foi referido na parte introdutória do presente artigo, no PE contemporâneo o pretérito imperfeito emprega-se com valores hipotéticos com uma frequência cada vez maior, quer dizer, condicional ou eventual. Este uso já é considerado como um fenómeno que faz parte do Português-padrão ${ }^{7}$. O emprego deste paradigma com funções modais é de dois tipos básicos (Raposo 2013: 520):

1. em frases complexas condicionais. Este tempo pode aparecer em dois subtipos destas frases:

a) em frases condicionais eventuais orientadas para o presente:

- Se tivesse mais tempo, fazia mais coisas ${ }^{8}$.

b) em frases contrafactuais orientadas para o passado:

- Se o tivesse sabido, não ia lá ${ }^{9}$.

2. O segundo tipo é representado pelo emprego do pretérito imperfeito nas frases independentes ou frases paratáticas, ou seja, fora de construções condicionais. Nestes casos, este paradigma pode veicular o valor condicional, dependente duma condição implícita, ou eventual:

- Fazia isso à vontade.

Esta frase pode ser interpretada quer como eventual (espera-se que isso seja feito, mas não se tem a certeza sobre a realização do evento) quer como condicional. No último caso, a ação de fazer isso depende duma condição que não está explicitamente expressa na frase ("Fazia isso à vontade, se alguma coisa acontecesse.") (Raposo 2013: 522-523).

Outro emprego modal é representado pelos pedidos atenuados em que este paradigma pode ser usado em vez do condicional (Raposo 2013: 523-524; Cunha, Cintra 1999: 451):

- Podia (poderia) trazer-me um copo de água?

Outro efeito modalizador é representado pelo pretérito imperfeito quando este se emprega, em brincadeiras de crianças, para criar um mundo não-real (de brincadeira) (Raposo 2013: 523):

7 Pelo Português-padrão entende-se geralmente "conjunto dos usos linguísticos das classes cultas da região LisboaCoimbra“ (Cunha, Cintra 1999: 10).

8 Na oração principal deste tipo de frases, pode usar-se a forma do condicional faria que é, porém, menos frequente no PE contemporâneo.

9 Nestas frases, o pretérito imperfeito pode ser substituído por mais variantes: condicional simples (iria) ou composto (teria ido) e mais-que-perfeito composto (tinha ido). 
- Agora eu era o polícia e tu eras o ladrão.

Agora tentaremos responder a uma outra pergunta: quais os motivos do alargamento das funções denotadas pelo pretérito imperfeito no PE contemporâneo? Na nossa opinião, podemos dividir os motivos prováveis em duas categorias: fonéticos e semânticos. No que diz respeito aos primeiros, existe uma semelhança formal entre os paradigmas do pretérito imperfeito e do condicional simples dos verbos da segunda e terceira classe e de muitos verbos irregulares (comeria/comia, abriria/abria). Devido à grande diferenciação entre as sílabas tónicas e átonas (as tónicas pronunciam-se com uma energia enorme que causa uma debilitação da pronúncia das átonas) que caracteriza o PE contemporâneo, a sílaba átona -er- ou -ir- tende a ser pronunciada duma maneira enfraquecida ou reduzida. Este fenómeno leva à aproximação da pronúncia dos dois paradigmas. Segundo os princípios da analogia morfológica ${ }^{10}$, este fenómeno expande-se também à primeira classe verbal (falaria $>$ falava).

De entre os motivos semânticos pode ser destacada uma certa "vagueza" do significado temporal do pretérito imperfeito. Este paradigma denota ações que se situam no passado e são consideradas como se fossem "sem limites". Na realidade, os processos expressos por este tempo têm o seu início e o seu fim, mas ao invés do que acontece no pretérito perfeito simples, estes limites temporais não são importantes. Como vimos mais acima, os processos expressos por este paradigma podem prolongar-se até ao presente. Estas características fazem com que o pretérito imperfeito seja considerado um tempo alargado. Daí vem também a possibilidade do seu emprego na função da posterioridade no passado (futuro do pretérito). Neste papel, é concorrente do condicional simples. Na nossa opinião, todas estas características ajudam à deslocação frequente deste paradigma para o domínio modal (Raposo 2013: 523).

\section{Funcionamento do pretérito imperfeito no Português antigo}

Ao consultar as gramáticas históricas do Português (Huber 1986; Mattos e Silva 1989, 2006; Said Ali 2001; Hricsina 2015), ficamos a saber que, no Português antigo, os papéis temporais básicos do pretérito imperfeito eram idênticos àqueles que este paradigma denota na língua portuguesa moderna.

A função mais frequente era a expressão dos eventos anteriores ao momento da enunciação sem que sejam indicados os seus limites temporais:

- E leuou-ho a hũa cozinha omde elle moraua, na qual avia muytas gallinhas e carne de porco, com outros boos comeres; (Fabulário Português, 111-séc. XIV)

Tal como no Português contemporâneo, também no Português antigo, este paradigma exprimia frequentemente as ações passadas habituais ou repetidas:

10 A analogia morfológica é um fenómeno que se opera na evolução de línguas. De facto, é uma tendência para amoldar as formas raras e irregulares às formas predominantes e regulares, tipicamente dentro de paradigmas verbais. Trata-se dum tipo de assimilação morfológica (Hricsina 2015: 26). 
- Na hordenança de todollos desembargos tiinha el-rrei esta maneira: guantas pitiçoões lhe a elle davom, hiam a maão de Gonçallo Vaasquez de Gooes seu scrivam da puridade, e elle as dava a hũu escrivam quall lhe prazia... (Crónica de Dom Pedro, 103-séc. XV)

O pretérito imperfeito denotava também os processos passados simultâneos às outras ações pretéritas:

- [...] mas el-rrei dom Henrrique era homem de gram coraçom e esforço, e disse que nom quiria poer a batalha salvo em-na praça chãa sem avantagem nẽhũa. (Crónica de Dom Fernando, 33-séc. XV)

Este paradigma servia também para situar vagamente no tempo vários contos, lendas ou fábulas. Diferentemente do Português contemporâneo, para tal desiderato usava-se o verbo existencial haver ${ }^{11}$ (Said Ali 2001: 231):

• Conta que em hũua provincia avya hũu hõem bóó... (Said Ali 2001: 231)

Também no Português antigo, existia a possibilidade de usar o pretérito imperfeito para denotar uma ação posterior a outra passada. Este uso, porém, não era muito frequente (Mattos e Silva 1989: 424-426):

- El-rrei disse que per ne hu ua guisa nom podia taaes castellos poer em fielldade, ca diriam os do rreino que quiria dar a terra a gentes estranhas, nem as mill lanças que lhe rrequiria, que nom avia por bem de ficarem em seu rreino, mas que o senhorio de Bizcaya e Crasto d’Ordialles, e Soria a monssé Joaham que bem lhe prazia de o outorgar. (Crónica de Dom Fernando, 42-séc. XV)

No que diz respeito aos valores modais, o pretérito imperfeito empregava-se para exprimir pedidos atenuados ou respeitosos como no Português contemporâneo (Mattos e Silva 1989: 423):

- Queria de boa mente, padre, saber que obras fazia aqueste abade Equicio que taes dões recebeo de Nosso Senhor. (Mattos e Silva 1989: 423)

\section{Métodos de análise}

Repitamos os objetivos do presente artigo: 1. analisar qual o comportamento semântico do pretérito imperfeito na história da língua portuguesa (quais os papéis desempenhados por este paradigma) e 2. mostrar qual o período em que mudou o funcionamento desta forma (começou a usar-se em valores hipotéticos).

11 Nesta função, o verbo ser empregava-se sempre no pretérito perfeito simples (Said Ali 2001: 231). 
Para tal decidimos aproveitar o corpus linguístico $w w w . c o r p u s d o p o r t u g u e s . o r g{ }^{12}$ que permite fazer pesquisas diacrónicas. Neste corpus foi analisado o emprego do pretérito imperfeito na evolução do Português, ou seja, do século XIV até ao século XX. A pesquisa limitou-se ao Português Europeu. Para cada século foram escolhidas 200 ocorrências do paradigma em questão (a seleção dos exemplos analisados foi aleatória). Todos os exemplos analisados foram divididos em quatro categorias segundo o seu papel modo-temporal: 1. emprego temporal, ou seja, expressão das ações anteriores ao momento da enunciação ou dos processos simultâneos aos outros situados no passado (ao ponto de referência que fica no passado), 2. emprego modal em frases condicionais complexas ${ }^{13}, 3$. emprego modal em frases independentes com valores eventual ou condicional e 4. emprego modal em pedidos atenuados. Agora, passamos a mostrar os resultados da nossa pesquisa in corpora para cada século.

\section{Análise in corpora}

\subsection{Século XIV}

A análise feita no corpus www.corpusdoportugues.org mostrou que todas as 200 ocorrências analisadas pertencem à primeira categoria, ou seja, o pretérito imperfeito exprimia exclusivamente os valores temporais. O paradigma em questão denotava tanto ações anteriores ao momento da enunciação (exemplos 1-3) como também processos simultâneos aos outros situados no passado (exemplo 4).

(1) Et Éytor fazía ben sentir sua espada per hu andaua, ca el os marteyraua cõ ela de tal gisa que, a quenquer açertaua, nûca ja mays auja mester meestre pera o goreçer. (Cronica Troyana $)^{14}$

(2) E enton a vara que tiinha na mãão, com que tangia os bois, chantouha ë na herdade lavrada em que estava cõ elles ë estas razõões e disse: (Crónica Geral de Espanha de 1344)

(3) Et o ssol daua ënos escudos et nas armas, que erã douradas et rreluzíã. (Cronica Troyana)

(4) ...e esto dizia que lho fazia por que as gentes d'Espanha eram muy fortes em armas e a terra muy castellada e muy boa... (Crónica Geral de Espanha de 1344)

Os resultados da análise do subcorpus do século XIV são sumarizados no gráfico I.

12 O corpus elaborado por Mark Davies (BYU) e Michael J. Ferreira (Georgetown University) contém mais de 45 milhões de palavras nos textos provenientes dos séculos XIV-XX escritos em ambas as variantes principais do Português, respetivamente no Português Europeu e no do Brasil.

13 Neste tipo de emprego, não faremos diferença entre as frases condicionais eventuais orientadas para o presente e as contrafactuais orientadas para o passado visto que o nosso objetivo é principalmente averiguar qual o período em que o pretérito imperfeito começou a ser empregue em funções modais.

14 Na parte 5 do presente artigo, todos os exemplos provêm do corpus www.corpusdoportugues.org. 


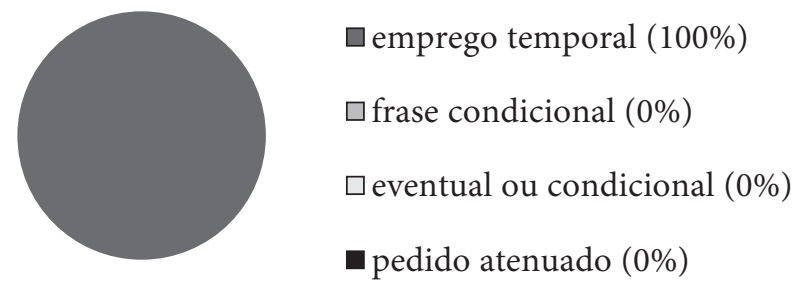

Gráfico I - Emprego do pretérito imperfeito no século XIV

\subsection{Século XV}

Tendo analisado as 200 ocorrências do pretérito imperfeito provenientes do século XV, ficamos a saber que, também neste século, este paradigma aparece quase exclusivamente em funções temporais (anterioridade ao presente ou simultaneidade no passado). Reparámos numa só frase em que este paradigma veicula o valor do condicional (frase complexa condicional) (ex. 8).

(5) E, com quanto escriveo, nom lhe vierom nem pode juntar em Evora mais que trinta lanças e com as duzentas que levava eram duzentas e trinta. (Crónica do condestável Nuno Alvarez)

(6) E Gaeriet, que amava muito Estor, esteve e rogou-lhi pola fé e pola companha que entre eles havia que lhi dissesse a verdade do que achara. (A Demanda do Santo Graal)

(7) E ali houve aquelo que desejava, convem a saber, jazer escondido em folgança da alma sua e haver fim e acabamento de sua vida em grande paz e assessego espritual. (Boosco deleitoso)

(8) Porë, a Deus merçes, \& a ell rrey de Portugall, \& ao comde com que vivë os que aquy estã presemtes, nunca o comemos, \& que ho comessemos allgûa vez, ysso nos trazia mais louvor que doesto. (Crónica do Conde D. Pedro de Meneses)

Vejam-se os resultados da pesquisa no subcorpus do século XV no gráfico II.

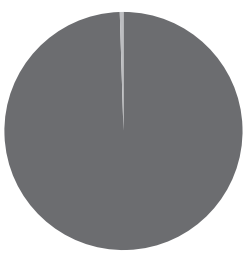

$\square$ emprego temporal $(99,5 \%)$

$\square$ frase condicional $(0,5 \%)$

$\square$ eventual ou condicional (0\%)

pedido atenuado (0\%)

Gráfico II - Emprego do pretérito imperfeito no século XV 


\subsection{Século XVI}

Os dados do século XVI apontam para a situação idêntica ao século XIV, ou seja, em todos os exemplos analisados encontrámos o pretérito imperfeito com funções temporais.

(9) E chegando as suas vacas começou tam feramente a peleijar com outro seu, que espanto fazia a ella, laa onde segura estava delles, no mais. (Bernardim Ribeiro, Menina e moça)

(10) E esta ribeira vinha por meio da cidade, passando pelo pe dos paços da infanta estrangeira, e saia por uma porta tão grande, que bem poderia entrar por ela uma nau com todas as velas, que o rio altura de agua tinha para isso. (João de Barros, Crónica do imperador Clarimundo)

(11) Algûas vezes aceitaua el Rei este dito, cõsolandose em hûs successos, \& nã queria aceitalo në ouuilo ë outros, \& o bõ homë que o tinha por costume sem nenhû dobres de ma licia o dizia geralmëte por tudo. (Gonçalo Fernandes Trancoso, Contos \& historias de proveito \& exemplo)

(12) E passadas as cerimónias da primeira vista, deu-lhe Pedrálvares a carta que levava del-Rei Dom Manuel. (João de Barros, Décadas da Asia (Década Primeira, Livros I-X))

(13) Clarindo, como não esperava tanto bem ficou mui alegre, e deu-lhe repetidas vezes muitas graças com palavras de tamanho amor quanto sempre depois mostrou com suas obras. (João de Barros, Crónica do imperador Clarimundo)

O gráfico III mostra os resultados da análise dos dados do subcorpus do século XVI.

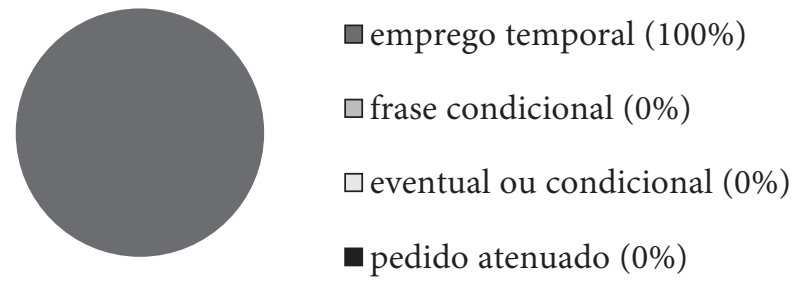

Gráfico III - Emprego do pretérito imperfeito no século XVI

\subsection{Século XVII}

Também no século XVII, a frequência do pretérito imperfeito com valores temporais é muito alta (ex. 14-16), enquanto que as outras funções são denotadas pelo paradigma esporadicamente. Neste século, encontrámos só um exemplo da frase condicional com uma expressão modotemporal haver de + infinitivo (ex. 17) e outro exemplo em que o pretérito imperfeito tem uma interpretação do valor eventual (ex. 18). Neste exemplo figura o verbo modal querer, que é típico desta função. Na análise das ocorrências do outro verbo modal dever, não reparámos, porém, em nenhum caso em que este verbo aparecesse com o valor eventual. 
(14) Um deles, que sabia menos que os mais daquela leitura, tinha tudo o que ouvia ler por verdadeiro (e assim há alguns inocentes que cuidam que se não pode mentir em letra redonda); os outros, ajudando a sua simpreza, lhe diziam que assim era. (Francisco Rodrigues Lobo, Côrte na Aldeia e Noites de Inverno)

(15) Não passou daqui o Provincial, conjeiturando porventura do silêncio e atenção com que se via escutado do Arcebispo que o tinha persuadido. E parando, esperava a reposta. (Luis de Sousa, A vida de Frei Bertolameu dos Mártires)

(16) Eu costumava dizer, quando andava pelo mundo, que os amores eram como os sapatos; porque andar uma creatura sem amor, é pouco menos que andar descalça; (Francisco Manuel de Melo, Letters)

(17) Dizia hum destes com travessura, que, se casasse, não havia de ser senão em Julho. (Francisco Manuel de Melo, Carta de Guia de Casados)

(18) E assim deveis saber como neste lugar há dois mancebos, um a quem amo, o outro a quem aborreço. Ao primeiro queria obrigar, ao segundo pretendo divertir. Ambos me querem muito, mas ao primeiro que se chama Leôncio, tenho entregue minha liberdade e merece ser querido e desejo por extremo que venha a ser meu esposo. (Gaspar Pires Ribelo, Infortunios trágicos da constante Florinda)

O gráfico IV sumariza os tipos das ocorrências do pretérito imperfeito no subcorpus do século XVII.

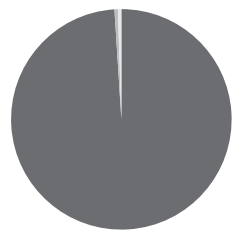

\author{
$\square$ emprego temporal (99\%) \\ $\square$ frase condicional $(0,5 \%)$ \\ $\square$ eventual ou condicional $(0,5 \%)$ \\ - pedido atenuado $(0 \%)$
}

Gráfico IV - Emprego do pretérito imperfeito no século XVII

\title{
5.5. Século XVIII
}

Ainda no século XVIII repete-se uma situação muito semelhante à verificada nos séculos anteriores: o valor do pretérito imperfeito claramente predominante é o temporal. Das 200 ocorrências deste paradigma analisadas deparámo-nos só com um exemplo em que o pretérito imperfeito tem uma interpretação modal, neste caso, o valor de eventualidade. Trata-se do verbo modal querer (ex. 23).

(19) ... e contou que acordara ao primeiro rumor, que eu fizera; e que de uma luz, que deixara junto à porta, pegara o fogo, e se achara sem mais remédio que esperar a morte, pois já nao podia respirar, nem tinha mais saída, que a que via embaraçada com as chamas. (Teresa Margarida da Silva e Orta, Aventuras de Diófanes) 
(20) Aqui um rouxinol, que sobre uma roseira, que fazia cortina à janela do coro, deixou de cantar à rosa por responder à freira: (Soror Maria do Céu, Aves ilustrados)

(21) Natália confortava ao seu Adriano e, pondo-lhe a mao no pescoco, dizia: Bem-aventurado és, dulcíssimo irmao meu, que te fez o Senhor digno de padeceres pelo seu nome; (Manuel Bernardes, Nova floresta)

(22) Todas estas cerimónias se $2^{\star}$ acompanhavam dum formulário de oraçoes, que se repetiam muitas vezes, com as quais se pedia a ternura e a brandura do objecto por que elas se faziam. (Francisco Xavier de Oliveira, Cartas familiares)

(23) Tanto queria agora escrever ao padre Sanhudo, e pesa-me que, com a pressa, não posso. (Antonio da Costa, Cartas)

Os resultados da pesquisa no subcorpus do século XVIII são mostrados no gráfico V.

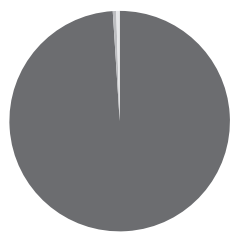

$\square$ emprego temporal (99\%)

$\square$ frase condicional $(0,5 \%)$

$\square$ eventual ou condicional $(0,5 \%)$

- pedido atenuado $(0 \%)$

Gráfico V - Emprego do pretérito imperfeito no século XVIII

\subsection{Século XIX}

No século XIX, deparamo-nos com uma situação ligeiramente diferente da verificada nos séculos anteriores: embora os valores temporais sejam sempre predominantes (194 ocorrências) (ex. 24-26), os casos em que este paradigma veicula uma interpretação modal, nomeadamente eventual, são mais frequentes. Importante é notar o facto de que todos os exemplos do pretérito imperfeito com o valor de eventualidade provêm do discurso direto (nomeadamente da obra de Eça de Queirós) e representam os verbos modais (dever, poder) (ex. 27-29). Registámos só um caso do eventual com outro tipo de verbo (fazer) (ex. 30). Daí pode deduzir-se que, muito provavelmente, o início do emprego do pretérito imperfeito com o valor eventual limita-se a um certo tipo de verbos (dever, poder) e à língua falada. Como se sabe, a língua escrita vem refletindo a evolução posteriormente à oralidade, por isso, opinamos que o pretérito imperfeito pode ter sido usado desta maneira já no século anterior, embora não se refletisse na literatura. É só no século XIX que alguns autores, sensíveis às mudanças linguísticas em curso, começam a registar esta tendência e a introduzem na sua obra.

O paradigma em questão aparece só uma vez na frase condicional (ex. 31).

(24) Oito dias depois, Macário era recebido em casa da Vilaça, num domingo. (Eça de Queirós, Singularidades de uma rapariga loura) 
(25) Amaro abriu o seu Breviário, ajoelhou aos pés da cama, persignou-se; mas estava fatigado, vinham-lhe grandes bocejos; (Eça de Queirós, O Crime do Padre Amaro)

(26) Mas aquelas orações, que ela recitava em pequena, não a consolavam; sentia que eram sons inertes que não iammais alto no caminho do Céu que a sua mesma respiração; (Eça de Queirós, O Primo Basílio)

(27) Não, senhor: o frade, que é patriota e liberal na Irlanda, na Polónia, no Brasil, podia e devia sê-lo entre nós; e nós ficávamos muito melhor do que estamos com meia dúzia de clérigos de requiem para nos dizer missa; (Almeida Garrett, Viagens na minha terra)

(28) Queixou-se do contínuo calor, da seca de Lisboa. Como devia estar lindo em Sintra - És tu que não queres - acudiu ele. - Podíamos fazer um passeio adorável. (Eça de Queirós, O Primo Basílio)

(29) Tens tu bacalhau? Devia haver, talvez. Que extravagância! Porquê? - Ai! - exclamou. Manda-me assar um bocadinho de bacalhau! (Eça de Queirós, O Primo Basílio)

(30) Não gracejo. É que realmente o meu procedimento.. não digo que fosse de uma sisudez exemplar, mas não merece as cores negras com que lho pintaram, nem reclama as medidas extremas e violentas que me propõem. Um casamento impossível! - Impossível! O que aí vai! Não o fazia tão fidalgo! Com que então. (Júlio Dinis, As Pupilas do Senhor Reitor)

(31) Entra, Titó! Os deputados já não usam farda, homem! Mas se a tivesse, com os diabos, ia hoje farda, e espadim e chapéu armado, para honrar hóspedes tão ilustres! (Eça de Queirós, A Ilustre Casa de Ramires)

O gráfico VI mostra os resultados da análise ao subcorpus do século XIX.

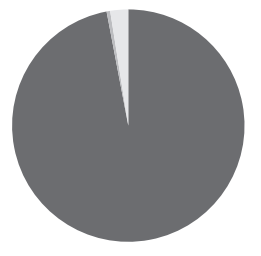

๑ emprego temporal (97\%)

$\square$ frase condicional $(0,5 \%)$

$\square$ eventual ou condicional $(2,5 \%)$

- pedido atenuado $(0 \%)$

Gráfico VI - Emprego do pretérito imperfeito no século XIX

\subsection{Século $\mathrm{XX}$}

Visto que, para o século XX, temos à disposição tanto o subcorpus da língua escrita (literário) como o da língua falada, decidimos fazer duas pesquisas. A primeira no subcorpus da língua escrita para podermos comparar os resultados com os séculos anteriores e a segunda no subcorpus da língua falada com objetivo de comparação da frequência do emprego do pretérito imperfeito com valores modais no Português escrito e falado no século XX. 


\subsubsection{Século XX-língua escrita}

Como era de esperar, no século XX a frequência do pretérito imperfeito com os valores modais passa a ser ainda mais alta do que no século anterior. Registámos 9 casos do paradigma em questão na função de eventualidade (ex. 35-40) e 3 casos do emprego do mesmo na frase condicional $(39,41,42)$. Acrescente-se também que o leque de verbos no pretérito imperfeito com função modal é alargado. A seleção de verbos não se limita a verbos modais, mas abrange também outros verbos ( gostar, custar, ficar, estar, ser). Este facto apoia a nossa hipótese sugerida no capítulo anterior, onde afirmamos que na fase inicial, eram essencialmente os verbos modais que adquiriam valores modais (séculos XVIII e XIX) e só depois a modalização foi alargada também a outros tipos de verbos (século XX). No entanto, o emprego do pretérito imperfeito com valores temporais verifica-se predominantemente também no século XX (188 ocorrências) (ex. 32-35).

(32) O velho lembrou-lhes que aquela terra estava estragada pelos brancos, que há muito tempo deixaram de comprar borracha, pagavam mal a fuba e o milho e só queriam gente forte para as minas, onde morriam os melhores homens da aldeia. (Castro Soromenho, Terra morta)

(33) A Anita esclareceu-me que a reza aproveitava a todos e que eu não podia abandonar a casa sem risco de se perder o efeito do que a minha mãe dizia e fazia. (Alves Redol, Fanga)

(34) Bem ouvia os outros, nos dias de leira, tocarem modinhas. Ele mirava-os de longe. E às vezes sentia ganas de entrar na do Filinto ou na do Qintino e mandar deitar um copo. (Alberto Lopes, A Ultima Estação)

(35) Mariano Paulo respondia numa voz frouxa: - Queria fazer dele alguma coisa. Não o tenha longe por gôsto. (Carlos de Oliveira, Uma Abelha na Chuva)

(36) As mulheres não compreendem certas coisas.. Se encontrasse um marido honesto e dedicado, ainda podia ser feliz, e eu ficava contente. (José Rodrigues Miguéis, Páscoa Feliz)

(37) Encontrei um homem muito simpático que tem uma casa parecida com aquela que os pais queriam ter quando fossem velhos e que gostava de viver numa casa como esta por ter luz e água e a dele não ter! (Rita Ferro, Por tudo e por nada: crónicas)

(38) Sobre a mesa da casa-de-jantar, entre dois pratos da companhia das índias, o Luís tinha encaixilhada uma das suas coroas de glória: o estalo da Michelle Pfeiffer. O que ele gostava que lhe perguntássemos: - Como é que foi este? (Rita Ferro, Por tudo e por nada: crónicas)

(39) E pensava: - Mas se tu quisesses eu cortava-tas. Não me custava nada, juro, até gostava! (Rita Ferro, Por tudo e por nada: crónicas)

(40) Não tenhas medo! Eu sei que vales mais do que isto, perdoa-me se insisto. Já está? Diz lá, então. Gostava de ser estrela ou horizonte... (Rita Ferro, Por tudo e por nada: crónicas)

(41) Se ficasse tudo por estes borrifos, até era bom, Bom para o patrão, está visto. (Miguel Torga, Vindima)

(42) -Ó filho, então não era melhor deixares-te ficar por aqui? -Com um dia destes?! Até era pecado. (Miguel Torga, Vindima) 
Os resultados da pesquisa no subcorpus do século XX (língua escrita) são apresentados no gráfico VII.

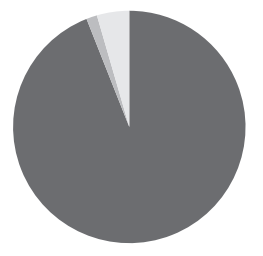

$\square$ emprego temporal (94\%)

$\square$ frase condicional $(1,5 \%)$

$\square$ eventual ou condicional $(4,5 \%)$

- pedido atenuado $(0 \%)$

Gráfico VII - Emprego do pretérito imperfeito no século XX-língua escrita

\subsubsection{Século XX-língua falada}

Os dados recolhidos do subcorpus da língua falada do século XX confirmaram a hipótese de que, na oralidade, o pretérito imperfeito adquire valores modais com uma frequência maior do que na língua escrita. Registámos 23 casos do emprego deste paradigma com função do eventual (com verbos variados) (ex. 43-46) e só 2 ocorrências na frase condicional (observação surpreendente) (ex. 47-48). O valor temporal era detetado em 175 casos.

(43) Hoje o mundo já não funciona pelo lado da oferta, onde se dava principal atenção ao consumo de massas e à partilha dos frutos do crescimento - e onde as políticas de esquerda, que são a minha referência, eram mais fáceis de executar. (Augusto Mateus)

(44) Depois dizia outra, aquela primeira que era do direito: eu gostava muito de ir a áfrica, mas o meu marido tem medo de andar de avião, desmaia assim. (Corpus-Ref-Port-Contemp: 560)

(45) R: Sim. Não é de opinião que a escola devia ser reconstruída? R: Com certeza. Deveria existir mais segurança na escola? R: Sim, quanto mais segurança melhor. Não acha que devia haver polícias à volta da escola? (Conselho Directivo (Professor Pedro))

(46) Qual é o livro do Eça que levava para a ilha deserta? R. - "Os Maias", que nas escolas até deveria ser interdito [risos]! (Maria Filomena Mónica)

(47) "Eu não conheço ninguém”. Se eu cá conhecesse, eu falava! Falava e sabia. E sabia pouco mais ou menos. (Cordial: ALV20)

(48) Se houvesse condições financeiras, do meu ponto de vista, não dava prémios por resultados mas dava-os proporcionalmente às receitas. (Miguel Galvão Telles)

Os resultados da pesquisa no subcorpus da língua falada no século XX são sumarizados no gráfico VIII. 


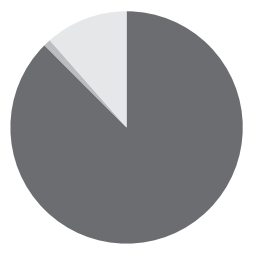

$\square$ emprego temporal $(87,5 \%)$

$\square$ frase condicional (1\%)

$\square$ eventual ou condicional (11,5\%)

- pedido atenuado $(0 \%)$

Gráfico VIII - Emprego do pretérito imperfeito no século XX-língua falada

\section{Conclusões}

A análise diacrónica do emprego do pretérito imperfeito no Português Europeu efetuada no corpus linguístico www.corpusdoportugues.org mostrou vários factos: 1. a função mais frequente expressa pelo paradigma em questão, durante toda a evolução do Português Europeu, é temporal (denotação dos processos anteriores ao momento da enunciação - passado), 2. o pretérito imperfeito com valores modais (eventual ou condicional) começa a aparecer duma maneira mais sistemática na língua escrita apenas no século XIX (até aí, tais ocorrências são mais ou menos esporádicas), 3. o paradigma analisado com valor de eventualidade até ao século XX emprega-se quase exclusivamente com certos verbos modais (poder, dever, querer), só no século XX começa a ser usado também com outros verbos, 4. o pretérito imperfeito com valores modais é mais frequente no Português falado do que na língua escrita. Considerando estes factos, podemos avançar a hipótese de que o início do emprego do pretérito imperfeito com valores modais deve procurar-se no século XIX ou no anterior, sabendo-se que a língua escrita vem refletindo a evolução posteriormente à oralidade. A análise mostrou também um outro facto relativamente interessante: uma frequência muito baixa do pretérito imperfeito nas frases condicionais, observada durante toda a evolução do Português Europeu.

\section{Referências bibliográficas}

Bechara, E. (2009). Moderna gramática portuguesa. Rio de Janeiro: Editora Nova Fronteira. Cuesta, P. V., \& Luz, M. A. M. da. (1980). Gramática da Língua Portuguesa. Lisboa: Edições 70.

Cunha, C., \& Cintra, L. (1999 $\left.{ }^{15}\right)$. Nova Gramática do Português Contemporâneo. Lisboa: João Sá da Costa. Hamplová, S. (1996). Stručná mluvnice španělštiny. Praha: Academia. . (2004). Mluvnice italštiny. Praha: Leda.

Hendrich, J., Radina, O., \& Tláskal, J. (1991). Francouzská mluvnice. Praha: SPN.

Hricsina, J. (2015). Vývoj portugalského jazyka. Praha: Karolinum.

Huber, J. (1986). Gramática do Português Antigo. Lisboa: Fundação Calouste Gulbenkian.

Mateus, M. H. M. et alii. (20046). Gramática da língua portuguesa. Lisboa: Caminho. 
Mattos e Silva, R. V. (1989). Estruturas Trecentistas. Lisboa: Imprensa Nacional - Casa da Moeda. . (2006). O português Arcaico fonologia, morfologia e sintaxe. São Paulo: Editora Contexto.

Oliveira, F. (1986). Algumas considerações acerca do p. Imperfeito. In Actas do $2^{\circ}$ encontro da Associação Portuguesa de Linguística (pp. 78-96). Lisboa: APL.

Raposo, E. P. et alii. (2013). Gramática do Português - Volume I. Lisboa: Fundação Calouste Gulbenkian. Said Ali, M. $\left(2001^{8}\right)$. Gramática Histórica da Língua Portuguesa. São Paulo: Editora Melhoramentos.

Svobodová, I. (2014). Morfologie současného portugalského jazyka II. Sloveso. Brno: Masarykova univerzita. Tláskal, J. (1984). Observações sobre tempos e modos em português. In Estudos de linguística portuguesa (pp. 237-255). Coimbra: Coleção linguística,.

Zavadil, B., \& Čermák, P. (2010). Mluvnice současné španělštiny. Praha: Karolinum. 